Research Article

\title{
Rethinking the Water Leak Incident of Tunnel LUO09 to Prepare for a Challenging Future
}

\author{
Wen-Chieh Cheng $\mathbb{D}^{1,2,3}$ Ge Li $\left.{ }^{1}\right)^{2,3}$ Annan Zhou $\mathbb{D}^{4},{ }^{4}$ and Jian Xu $\mathbb{D}^{2,3}$ \\ ${ }^{1}$ Key Laboratory of Western China's Mineral Resource and Geological Engineering, Ministry of Education, \\ Xi'an 710054, China \\ ${ }^{2}$ School of Civil Engineering, Xi'an University of Architecture and Technology, Xi'an 710055, China \\ ${ }^{3}$ Shaanxi Key Laboratory of Geotechnical and Underground Space Engineering (XAUAT), Xi'an 710055, China \\ ${ }^{4}$ School of Engineering, Royal Melbourne Institute of Technology (RMIT), Melbourne, Victoria 3001, Australia \\ Correspondence should be addressed to Wen-Chieh Cheng; s2428030@gmail.com
}

Received 26 June 2019; Revised 3 September 2019; Accepted 10 September 2019; Published 7 October 2019

Academic Editor: Fan Gu

Copyright (c) 2019 Wen-Chieh Cheng et al. This is an open access article distributed under the Creative Commons Attribution License, which permits unrestricted use, distribution, and reproduction in any medium, provided the original work is properly cited.

\begin{abstract}
Incident often occurs while deepening excavation pit and/or tunnelling underground pipelines although serious attention from practitioners, engineers, and scientists has received. Prevention and mitigation of incident have thus been deemed to be the key in developing sustainable infrastructure in urban areas. This study analyses and discusses an extensive water leak incident taken place throughout the parallel tunnels LUO09 construction in the soft alluvial deposits in Kaohsiung, Taiwan. Dumping sand bags and quick-set cement intervened the incident but in vain. The water leak incident is initiated by the piping. The existing vehicle underpass causes the jet-grout columns installed not exactly in the plumb. Their overlapping is estimated to be less than the design value of $60 \mathrm{~cm}$, and some seepage-prone weak zones are thus developed. The measured hydraulic gradient being equal to 12.1 and existence of seepage-prone weak zones are deemed as the main cause initiating the water leak incident. The pinhole test results highlight not only the nonplastic nature of the Kaohsiung silt but also its vulnerability to piping under large hydraulic gradients. Some bullet points that indicate what engineers should do or avoid are learned and summarised.
\end{abstract}

\section{Introduction}

Braced excavation and/or shield tunnelling in soft ground with high piezometric levels leads to a high potential to trigger water leak incident. Such water leak into excavation pit or sewage pipeline can result in-ground collapse and damages to adjoining facilities. Prevention of such a leaking incident has thus been deemed to be the key in developing sustainable infrastructure in urban areas. Jo et al. [1] indicated that the migration of the fine particles mainly contributed to the ground sinking incident occurred in Seoul, Korea. Hou et al. [2] declared that the combined effects of the sewage pipeline corrosion, soil strength deterioration, and construction disturbance triggered a $20 \mathrm{~m}$ long, $14 \mathrm{~m}$ wide, and $12 \mathrm{~m}$ deep cave-in throughout soft soil tunnelling of Beijing metro line 10. Chen et al. [3] indicated that the ground collapse occurred in a $15.7 \mathrm{~m}$ deep excavation in very sensitive clay in Hangzhou, China caused damages to the retaining structure and the water main and led to ground sinking of a road next to the excavation. Feng and $\mathrm{Lu}$ [4] reported that the bislurry grouting failed to stop the seepage causing a failure of retaining structure installed in very thick sand layers with a high phreatic surface during a metro station excavation in Nanchang, China. Tan and $\mathrm{Lu}$ [5] indicated that a flawed slab connector embedded in the silt and sand layers has been deemed as being the main cause to lead to a sudden outburst of groundwater while deepening a subway excavation in Shanghai, China. The above studies indicate that incident often occurs, accompanied with significant casualties and economic losses, while developing infrastructure in urban areas [6-15] and relates mostly the phenomenon of water leak despite several protective 
measures available [15-23]. In spite that serious attention has been drawn, consensus on prevention and mitigation measures has not reached yet.

The objectives of this study are (1) to analyse and discuss the water leak incident occurred while deepening the middle sump pit of the parallel tunnels LUO09, (2) to reveal the triggering mechanism, with reference to the testimony from the men at work and the field measurements, and (3) to suggest preventive measures against similar leaking incident.

\section{Description of Case History}

2.1. Background. Two $837 \mathrm{~m}$ long, $6.1 \mathrm{~m}$ wide parallel tunnels LUO09 were excavated using the shield tunnelling method. A $6.24 \mathrm{~m}$ diameter earth pressure balance (EPB) shield was responsible for tunnel boring operations. Their ends are linked to the stations $\mathrm{O} 7$ and $\mathrm{O} 8$ of the Kaohsiung metro system, and a cross passage with a middle sump pit at $32.6 \mathrm{~m}$ depth was built for safety purpose. Several boreholes that penetrate through a $42 \mathrm{~m}$ thick alternating layer of soft clay and silty sand and into a more than $30 \mathrm{~m}$ thick silty gravel were installed providing a detailed description of the field geological conditions (Figure 1). The groundwater level was at 5-6 $\mathrm{m}$ depths below the ground surface.

A series of $3.2-3.5 \mathrm{~m}$ diameter jet-grout columns at the depth of $35 \mathrm{~m}$, with a mutual overlapping of $60 \mathrm{~cm}$, were installed in the vicinity of the cross passage using the super jet-midi (SJM) method because of the surrounding silty sand of high permeability [26]. The grouting tubes, while boring operations, were installed with horizontal included angles because of the existing overlying vehicle underpass. Upon completion of the cross passage, the $3.3 \mathrm{~m}$ diameter sump pit was excavated.

\subsection{Incident, Associated Damage, and Remedial Measure.} It was noticed that an outburst of mud water occurred while excavating to near the bottom of the sump pit (Figure 2(a)). Authorities immediately responded to the water ingress event by dumping sand bags and quick-set cement but in vain. Men at work soon heard sounds of breaks at liner joints of the tunnel on the south side, with water leaked into the tunnel from the ripped liner joints. The water also carried away fine particles, and the tunnel due to this reason lost contact with the ground leading to stepwise surface settlement in the longitudinal direction. More soil, while the settled cone expanded upwards, fell by slipping along the vertical wall of the vehicle underpass and passing through the ripped liner joints into the tunnel. Not only serious ground loss but also two undermined water mains transferred the soil into more flowable debris, causing a large surface cave-in on the south side (Figures 2(c) and 3(a)).

The ground loss also caused the tunnel on the north side to sink, accompanied by the offsets of the liners (Figure 3(b)). The soil fell into the tunnel mainly from the liner offset at the junction between the tunnel and the cross passage, leading to another surface cave-in (Figures $2(\mathrm{~d})$ and 3(a)). To summarise, the amount of earth and quick-set cement dumped to fill the surface cave-ins was estimated to be as much as $12,000 \mathrm{~m}^{3}$, whereas the water inflow, resulting from the two undermined water mains, was approximately $2,000 \mathrm{~m}^{3}$. Then, a 2-year rehabilitation was carried out to resume the traffic and its activities are detailed as follows (Figure 4):

(i) Two watertight plugs within the tunnels at some distance from the point of water ingress were to secure the watertight effectiveness with additional jet-grout blocks

(ii) Porewater within the surrounding soil was frozen using the ground freezing method

(iii) Diaphragm walls of $1.5 \mathrm{~m}$ in thickness to retain the excavation-induced lateral loads were constructed at the depth of $60 \mathrm{~m}$

(iv) Dewatering wells screened at the bottom of the tunnels were constructed to secure the excavation face dry

(v) The removal of the undermined vehicle underpass was conducted upon completion of Region "II" excavation

(vi) New tunnel liners were erected following completion of Region "I" excavation

(vii) Controlled low-strength materials (CLSM) was backfilled to the bottom of new vehicle underpass allowing for new vehicle underpass installation

(viii) CLSM was backfilled to the surface

2.3. Field Instrumentation Data. Such serious ground loss caused two surface cave-ins to be developed on the south and north sides, respectively. The tunnel on the south side and the vehicle underpass due to loss of the contact with surrounding ground significantly settled $2.7 \mathrm{~m}$ and $1 \mathrm{~m}$, respectively. The tunnel on the north side showed a relatively small settlement of $0.16 \mathrm{~m}$. Additionally, the adjacent railway also measured some settlements and track relative displacements. As discussed, the diaphragm walls with the frozen ground and soilcrete blocks aimed to secure the watertight effectiveness while progressing the rehabilitation. The rehabilitation including the removal of undermined vehicle underpass and the erection of new tunnel liners as well as the installation of new vehicle underpass was performed when the water inside the walls was drained using the pumping wells and when the earth inside was removed. Therefore, the proposed layout of monitoring instruments (Figure 5) intended not only to observe the groundwater level and surface settlement variations while progressing the rehabilitation but to assess the associated environmental impacts.

Prior to progressing the rehabilitation, a group-well pumping test was performed using eight pumping wells installed inside the diaphragm walls. Figure 6 presents the variations of the groundwater levels and the number of pumping wells opened during the group-well pumping test. The group-well pumping test consisted of the pumping phase and recovery phase, and each phase continued for about 7 consecutive days. Table 1 lists the monitoring 


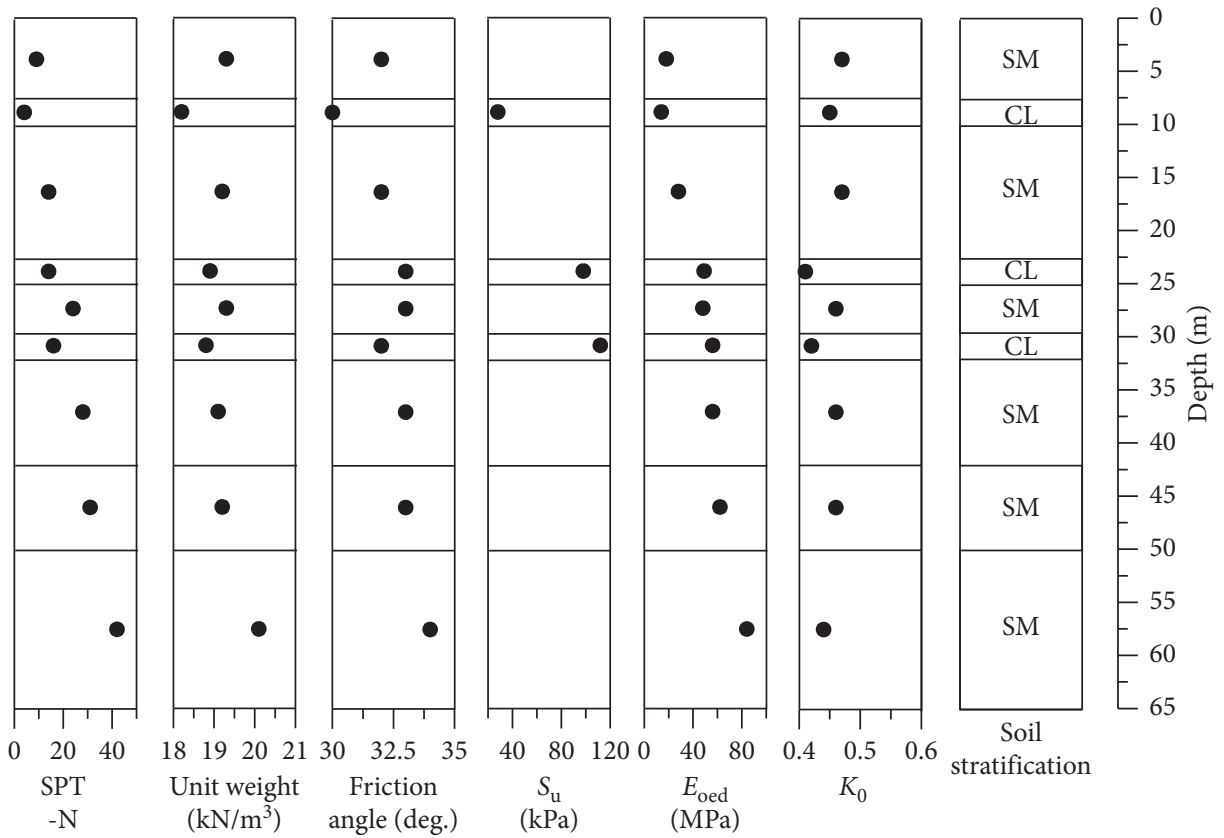

Figure 1: Soil properties profile. $\mathrm{CL}=$ silty clay; $\mathrm{SM}=$ silty sand; $S_{\mathrm{u}}=$ undrained shear strength; $K_{0}=$ earth pressure coefficient at rest; $E_{\text {oed }}=$ elastic modulus from oedometer test.

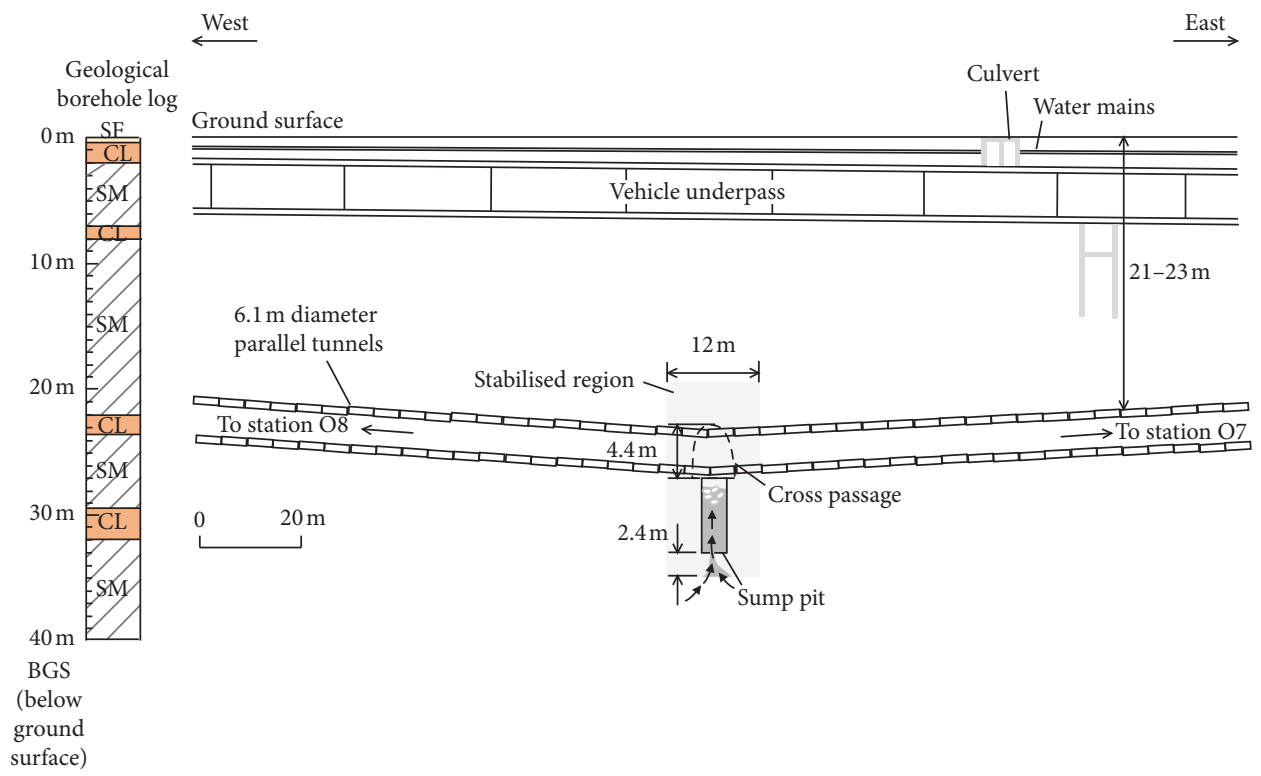

(a)

FIgURE 2: Continued. 


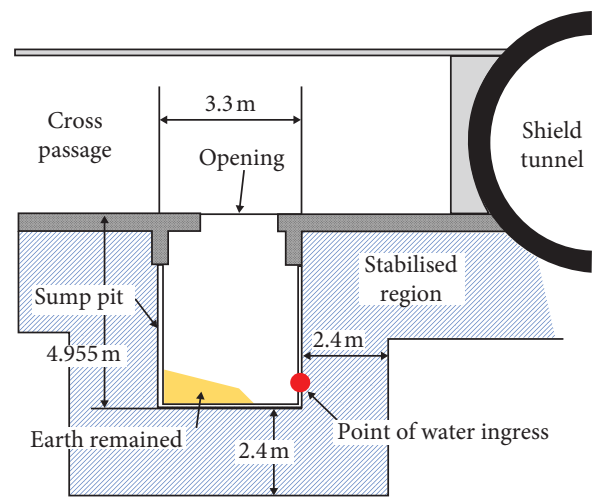

(b)

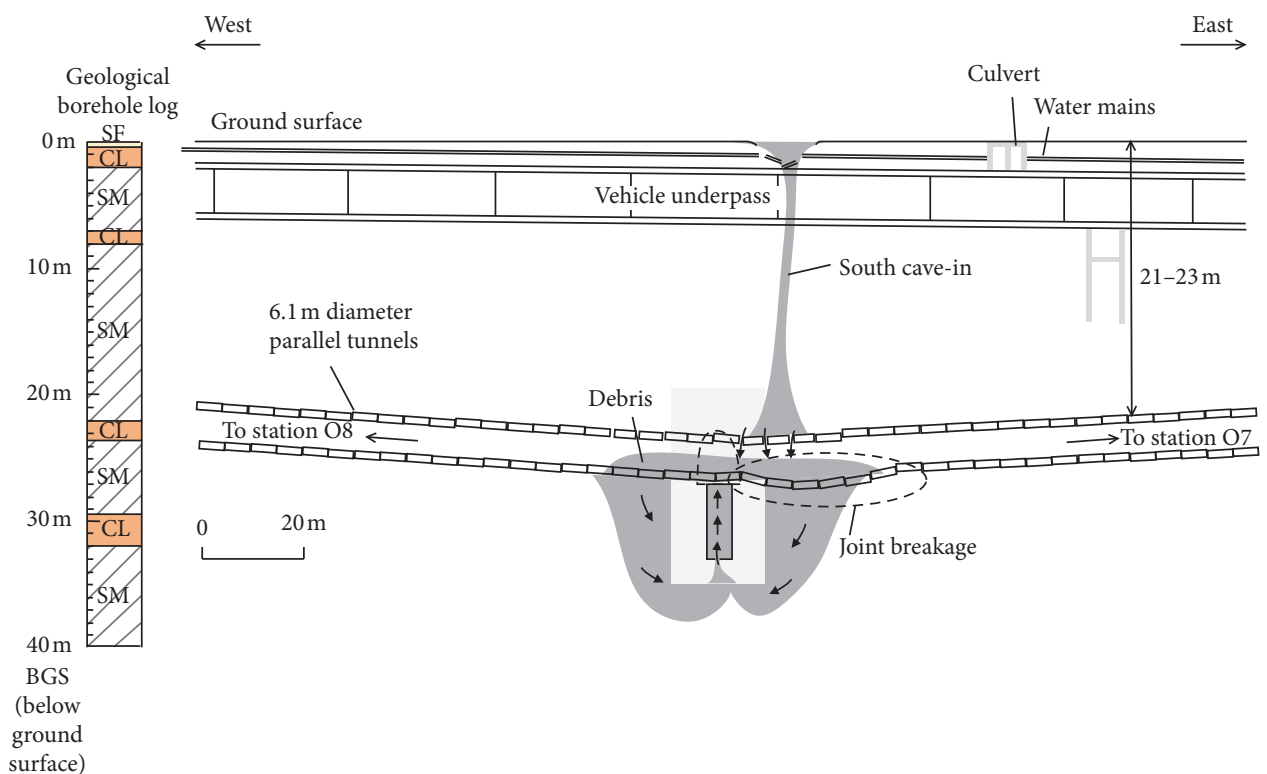

(c)

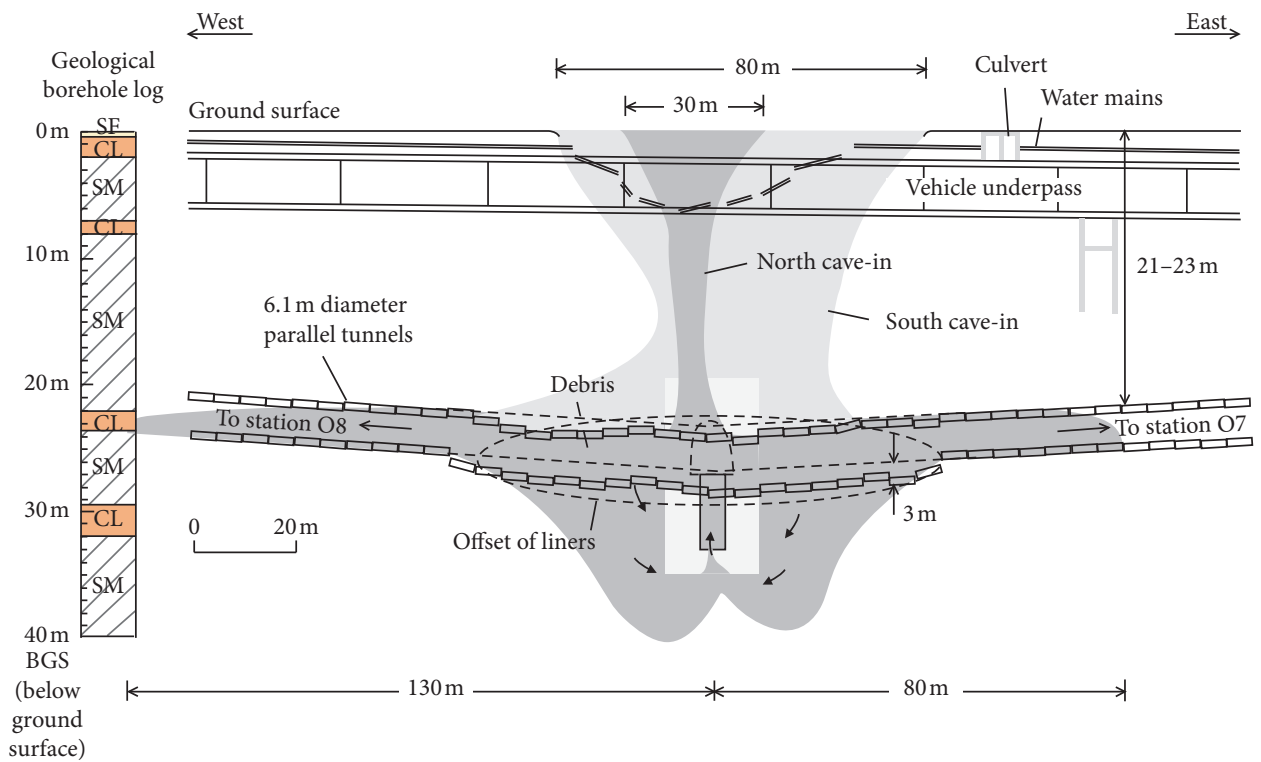

(d)

FIGURE 2: Scenario for progressing the water leak incident: (a) water leak (SF: backfill; SM = silty sand; CL: low plasticity clay), (b) illustration of the shortest path for groundwater seepage, (c) formation of the surface cave-in on the south side, and (d) formation of the surface cave-in on the north side (SF: backfill; SM = silty sand; CL: low plasticity clay). 


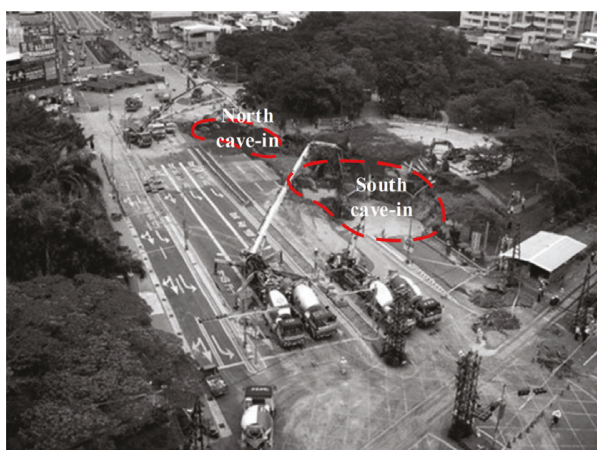

(a)

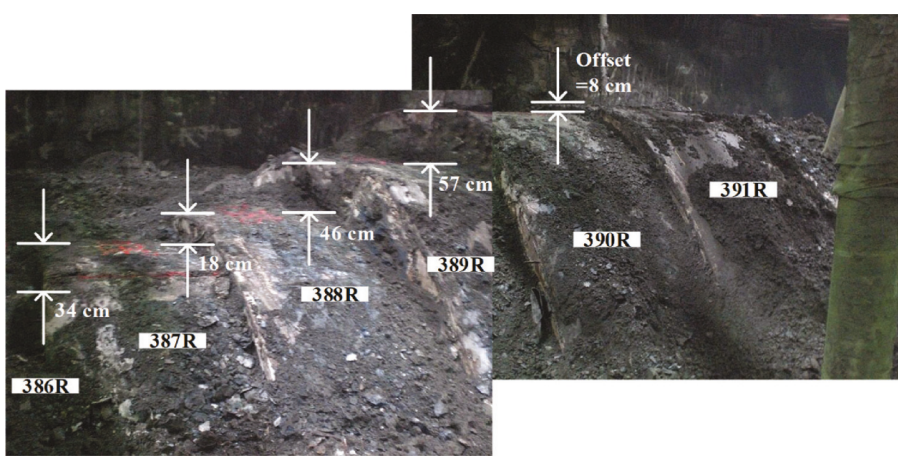

(b)

Figure 3: Photos taken from the water leak incident: (a) two surface cave-ins and (b) offsets of tunnel liners.

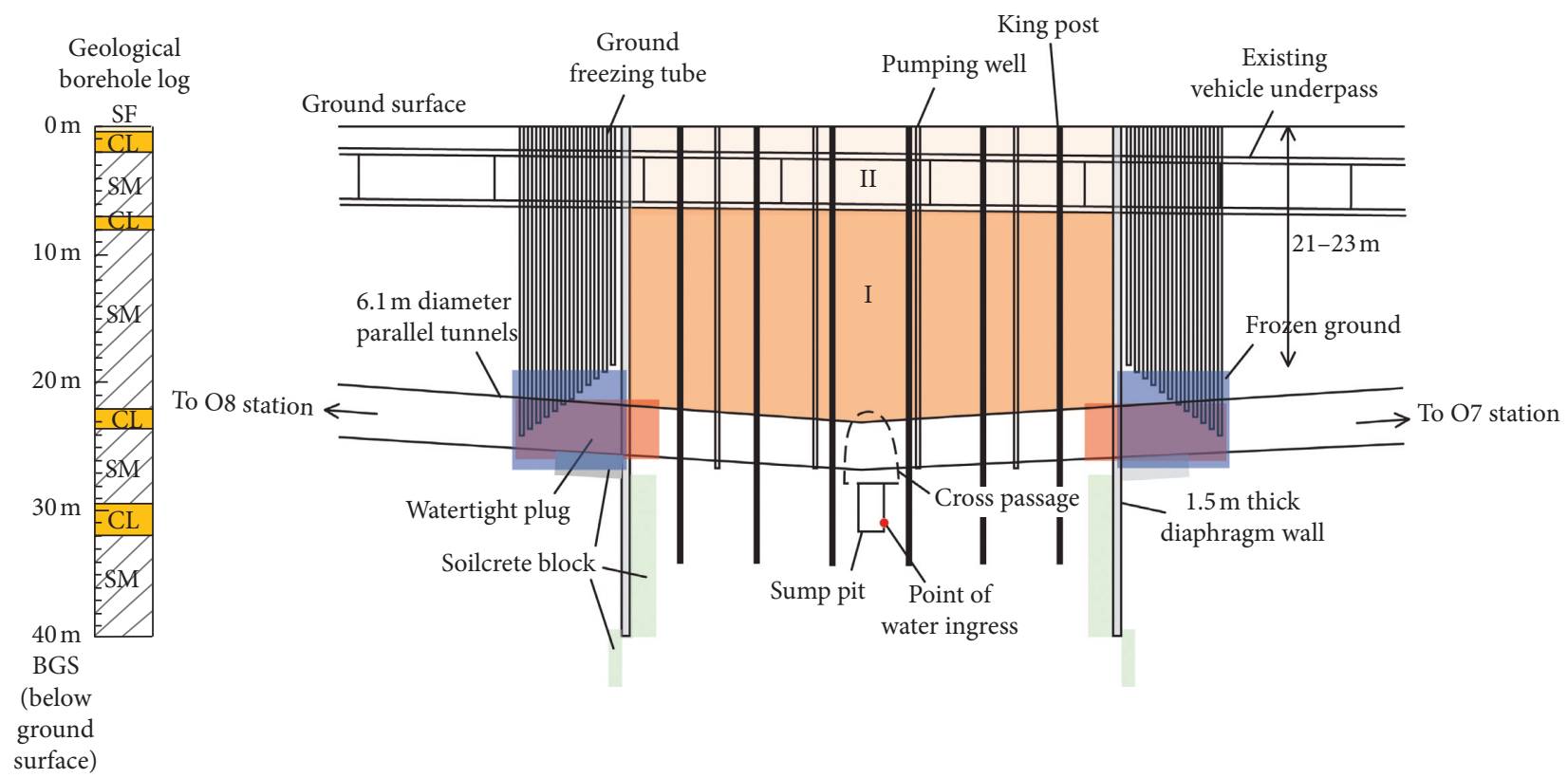

FIGURE 4: Schematic illustration for progressing the rehabilitation. Note: Soil in Regions I and II to be removed in the rehabilitation and then backfilled to the surface upon completion of the tunnel liners erection and new vehicle underpass installation. Note: soil in Regions I and II to be removed in the rehabilitation and then backfilled to the surface upon completion of the tunnel liners erection and new vehicle underpass installation. SF: backfill; $\mathrm{SM}=$ silty sand; CL: low plasticity clay.

instruments used in the test. It can be seen from Figure 6 that the groundwater levels in the observation wells OW-S1, OW-S2, OW-04, and OW-10 declined sharply to the 33$35 \mathrm{~m}$ depths in the very beginning of the pumping phase and maintained almost constant until the end of the pumping phase. A similar tendency, but with smaller variation, was observed from the observation wells OW-02 and OW-08. There was a sudden increase in the groundwater levels right before the completion of the pumping phase, most likely because of the recharge effect resulting from a rainfall. The recovery rates of the observation wells OW-S1, OW-S2, OW-04, and OW-10 gradually declined from $1.2 \mathrm{~m} /$ day in the beginning of the recovery phase to $0.1-0.2 \mathrm{~m} /$ day in the end of the recovery phase. Except the duration of rainfall, the groundwater level in the observation well OW-14 remained almost constant, indicating that the group-well pumping appeared to have negligible influence on the groundwater level outside the diaphragm walls, which also indicated good watertight effectiveness.

Figure 7 shows the variations of the ground surface settlements while progressing the rehabilitation. The surface settlement point SM-T1 measured the smallest settlement, compared with the surface settlement points SM-T2, SM-T3, SM-T4, SM-A, SM-B, and SM-C. Similarly, the surface settlement points SM-01, SM-02, SM-04, SM-06, and SM-07 measured the relatively small settlements, compared with the surface settlement points SM-03 and SM-05. This phenomenon is due to the fact that the indicated surface settlement points were all close to the short side of excavation pit and the diaphragm walls of the short side due to its larger bending stiffness than those of the long side exhibited smaller lateral deflection and surface settlements. Despite 


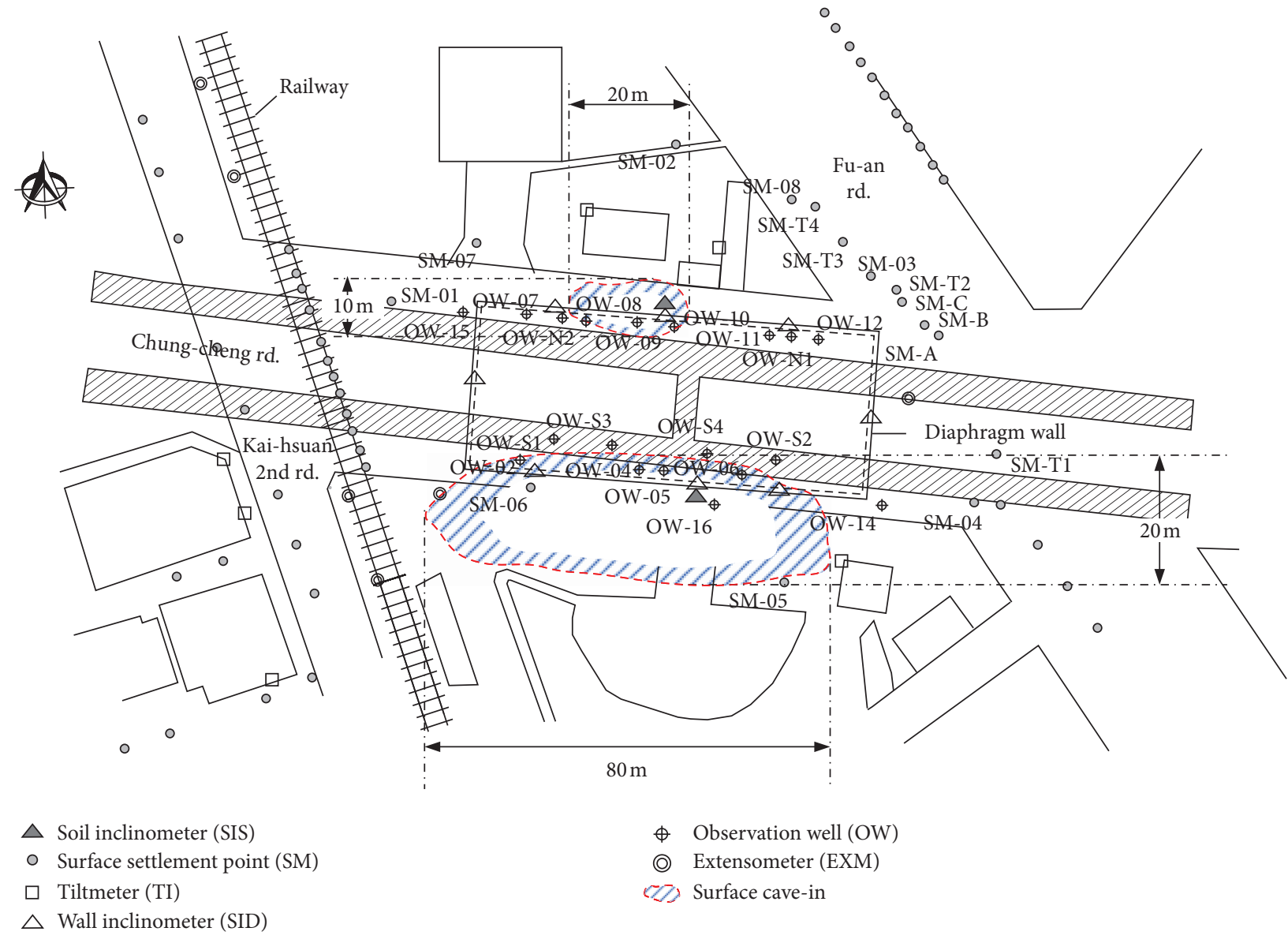

FIGURE 5: Layout of monitoring instruments and locations of surface cave-ins.

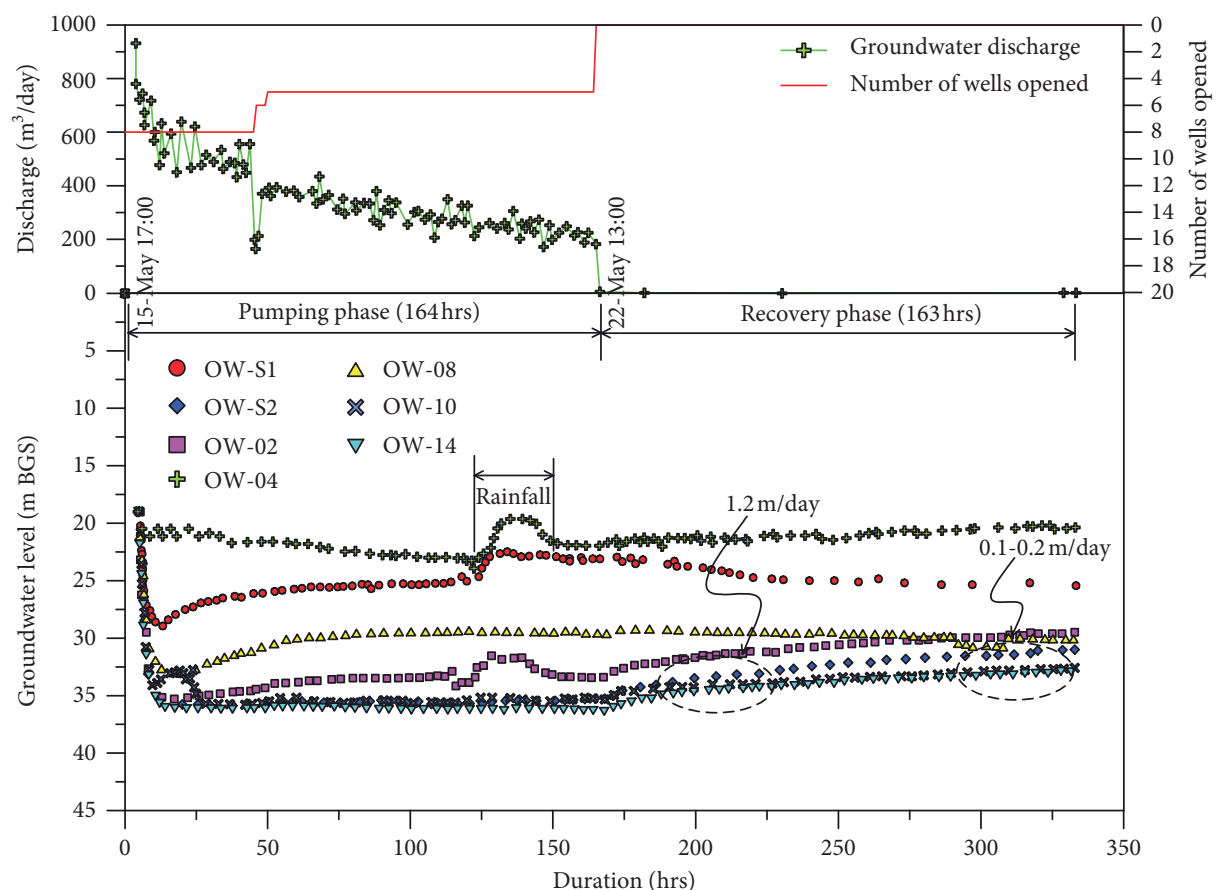

FIGURE 6: Variations of groundwater levels for verification of watertight effectiveness. 
TABLE 1: Details for the monitoring instruments used in the pumping test.

\begin{tabular}{llcr}
\hline Location & Well type & Instrument no. & Depth (m) \\
\hline & Observation well & OW-S1 & 40 \\
& Observation well & OW-S2 & 45 \\
Inside the diaphragm wall & Observation well & OW-02 & 45 \\
& Observation well & OW-04 & 45 \\
& Observation well & OW-08 & 45 \\
\hline Outside the diaphragm wall & Observation well & OW-10 & 45 \\
\hline
\end{tabular}

the unignorable contribution from the effects of the diaphragm wall construction and the strut removal to the ground surface settlements, the associated increases were typically $4.8-9.4 \mathrm{~mm}$ and $5.5-7.5 \mathrm{~mm}$, respectively, for SM$A$ to $C$ and SM-T1 to T4 and $1-13 \mathrm{~mm}$ and $8.2-13.1 \mathrm{~mm}$, respectively, for SM-01 to 07. While the pit excavation appeared to have minimal influence on the ground surface settlements, it is worth to mention that when the ground was unfrozen prior to the installation of new vehicle underpass, the ground surface settlements increased very quickly, especially for SM-01 to SM-07. Despite the increases in the surface settlement, the surface settlements then soon reached a steady state condition.

\section{Analysis and Discussions}

3.1. Triggering Mechanism. The piping phenomenon was responsible for initiating the water leak incident, with reference to the testimony of workmen. Notwithstanding that, the initiation of piping was conceived variously. The existing vehicle underpass, in fact, led to some difficulties in installing the jet-grout columns exactly in the plumb. Thus, the overlapping of jet-grout columns was estimated to be less than the design value of $60 \mathrm{~cm}$, and some seepage-prone weak zones were thus developed. On the other hand, as the groundwater level was at 5-6 $\mathrm{m}$ depths below the ground surface, the head difference between the groundwater level and the $34 \mathrm{~m}$ depth where the piping initiated was $29 \mathrm{~m}$. The length of the shortest path for groundwater seepage was from the bottom of the soilcrete body to the point of water ingress, that is, $2.4 \mathrm{~m}$ (Figure 2(b)). This came out with the hydraulic gradient $i$ being equal to about $12.1(i=29 \mathrm{~m} / 2.4 \mathrm{~m}=12.1)$. The critical hydraulic gradient $i_{\mathrm{cr}}$ for triggering piping within gap-graded sand-gravel mixture could be as low as $0.2-0.3$ as compared to $i_{\mathrm{cr}}=0.9-1.0$ for clean sands [26]. In spite that this might not be true for the Kaohsiung soil with the finer particle-size range, the soil particles could easily be detached or washed away as subjected to such a high hydraulic gradient of 12.1. It is evident that the seepage-prone weak zones allowed the water to flow through the jet-grout columns and into the sump pit and that this high hydraulic gradient made the water inflow even greater. The combined effects of high hydraulic gradient and existence of seepage-prone weak zones were deemed as the main cause to initiate the water leak incident.

3.2. Soil Erodibility. Sherard et al. [26] described the pinhole test where water flows through a $1 \mathrm{~mm}$ diameter hole punched in a specimen of compacted clay and the water emerging from dispersive clay carries a suspension of colloidal particles [27]. Sherard et al. [28] then utilised the pinhole test to investigate erosion in clay-silt mixtures in response to the problem emerging from occasional failure of low-height earth dams which occurred upon water filling in Australia and U.S. The pinhole test provides a direct qualitative measurement of the dispersibility or deflocculation and consequent erodibility of clay soils as stated in ASTM standard D4647-93 [29]. There were seven $33 \mathrm{~mm}$ diameter, $25 \mathrm{~mm}$ height specimens tested in the pinhole test for which their properties are summarised in Table 2. The average grain size $\mathrm{D}_{50}$ for the specimens was about $0.075 \mathrm{~mm}$. A steel nipple was pushed into the specimen, and the hole was punched through the nipple as a guide hole using a $1 \mathrm{~mm}$ diameter steel needle. Wire screen and pea gravel were placed in the pinhole cell on either side of the specimen, as shown in Figure 8. As the pinhole cell assembled, distilled water was allowed to percolate through the specimen under constant heads of 50, 180, 380, and $1020 \mathrm{~mm}$, in accordance with ASTM standard D4647-06. The principal differentiation between dispersive and nondispersive soils, however, is given by the test results under $50 \mathrm{~mm}$ of head, as suggested by Sherard et al. [26], indicating that there is no necessity to carry out the test through to $1020 \mathrm{~mm}$ of head. The purpose to further increase the head is to classify dispersive soils, which is not within the scope of this study. The effluent turbidity and size of pinhole at the end of each test were recorded. If the effluent remains clear and the pinhole size unenlarged, then the soil is nondispersive. Contrarily, the effluent is turbid and the pinhole size is enlarged for dispersive soil.

Table 3 summarises the results of the pinhole test. For the specimens which were categorised as $\mathrm{D}$, they were dispersive soils. There was also a common characteristic. Most of the specimens primarily included silt with a fines content varying from 52 to $96 \%$ [30] and their Unified Soil Classification System (USCS) symbols were ML and SM-ML. The pinhole size enlarged in a range of 2-4 $\mathrm{mm}$ after the test. The specimen S-19 categorised as ND was nondispersive soil with a fines content of $94 \%$ and mainly consisted of clay. The USCS classified this specimen as CL, which was an indication of low plasticity clay. The pinhole size for the specimen S-19 remained unenlarged after the test. The test results revealed a fact indicative of the tendency of the silt from Kaohsiung, Taiwan to possess high dispersion, or very low strength, or both. The particle-size distribution analysis indicated that the Kaohsiung soil belonged neither to the gap-graded gravelly 


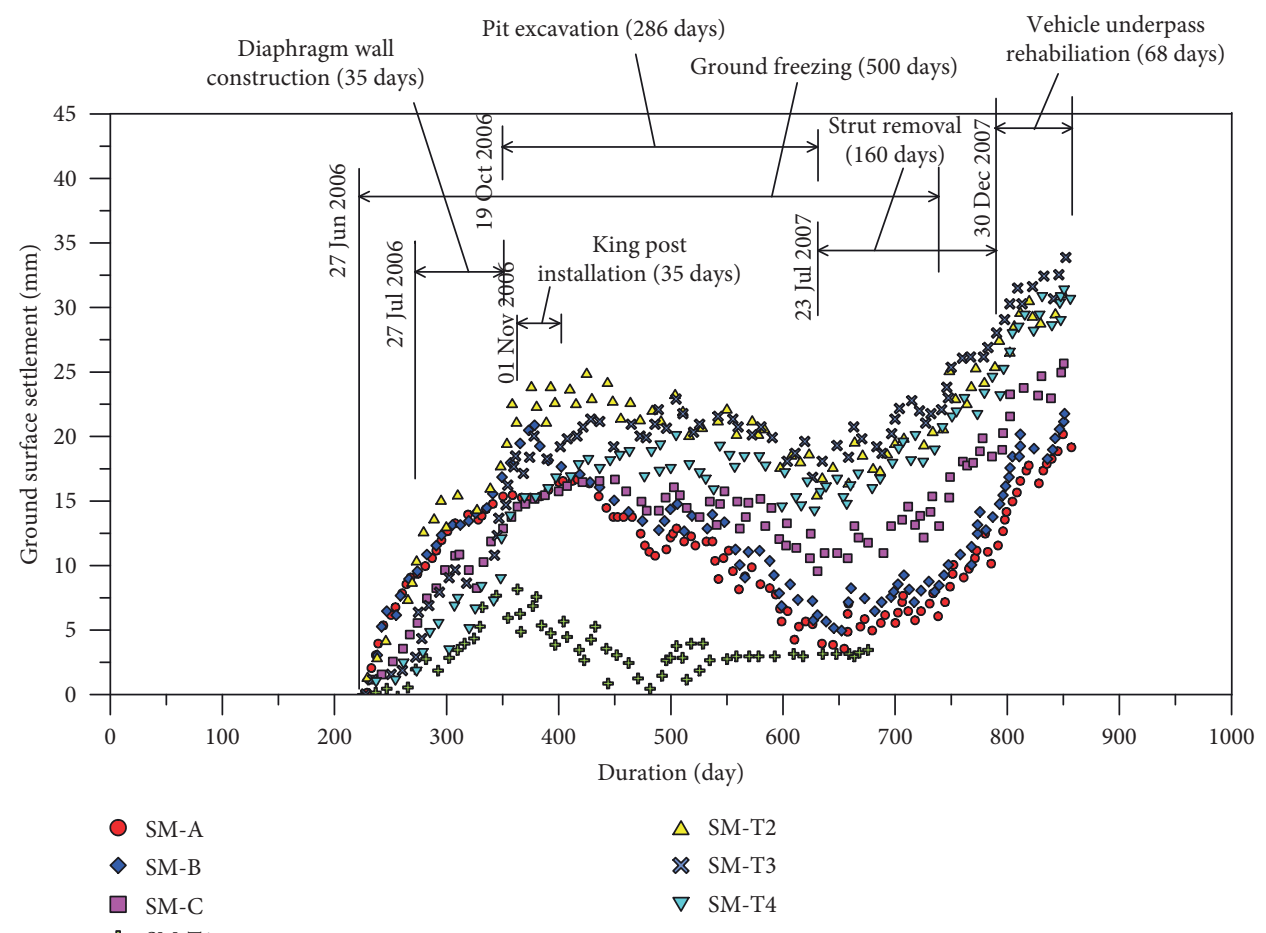

(a)

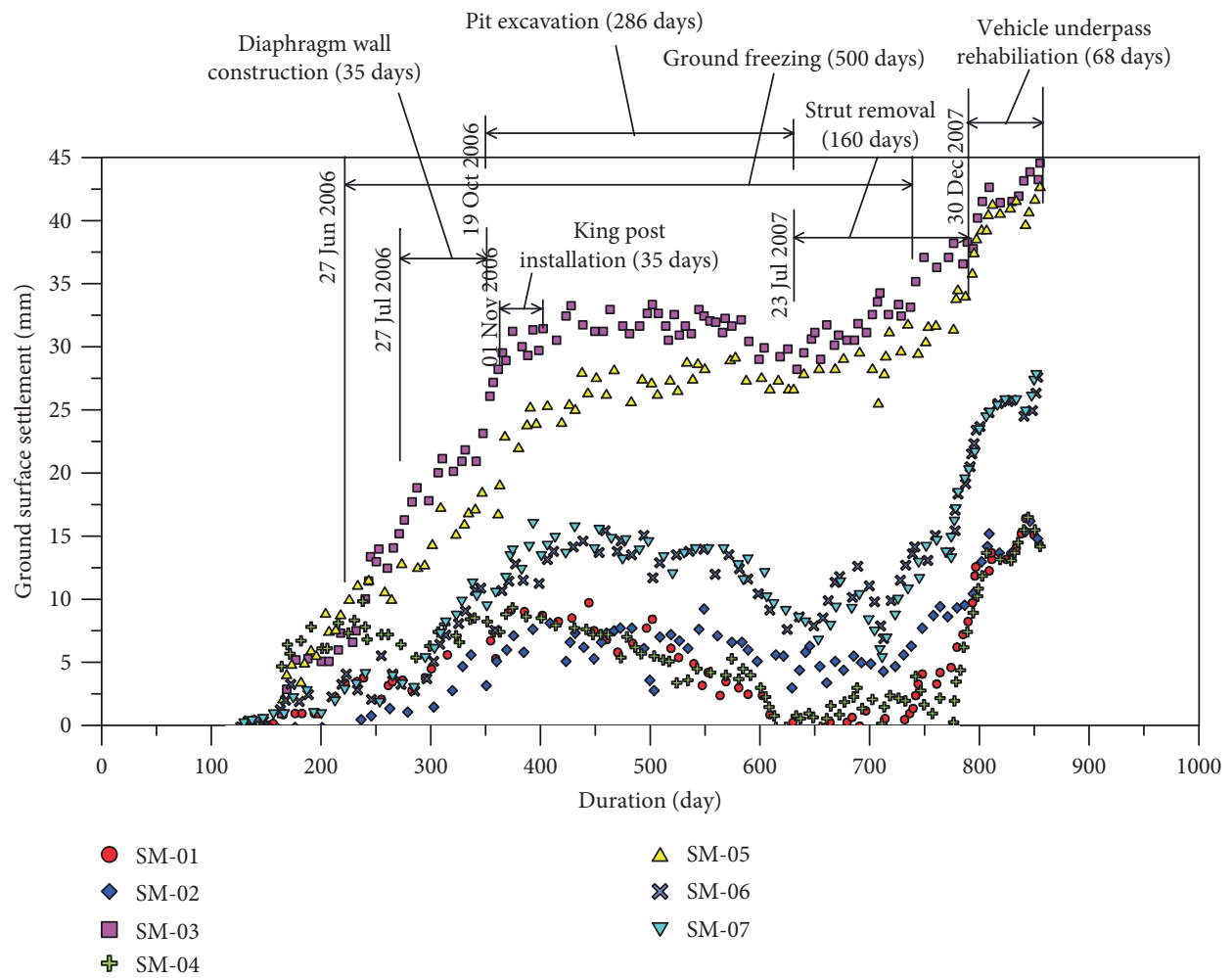

(b)

FIGURE 7: Variations of ground surface displacements for progressing the rehabilitation: (a) SM-A to C and SM-T1 to T4 and (b) SM-01 to 07 .

sands susceptible for segregation piping nor to the dispersive clay prone to internal erosion. In fact, the particle size for the Kaohsiung soil lay midway in the range of silt and sand. The pinhole tests were regarded as an effective means to identify not only the nonplastic nature of the Kaohsiung silt contained in the sand but also its high vulnerability to piping or internal 
TABLE 2: Summary of soil properties in the pinhole test.

\begin{tabular}{|c|c|c|c|c|c|c|c|c|c|}
\hline $\begin{array}{l}\text { Specimen } \\
\text { no. }\end{array}$ & Depth (m) & $\begin{array}{l}\text { USCS } \\
\text { symbol }\end{array}$ & SPT-N & $\begin{array}{c}\text { Sand } \\
(\%)\end{array}$ & $\begin{array}{l}\text { Silt } \\
(\%)\end{array}$ & $\begin{array}{l}\text { Clay } \\
(\%)\end{array}$ & $\begin{array}{c}\text { Water content } \omega \\
(\%)\end{array}$ & $\begin{array}{l}\text { Liquid limit LL } \\
\text { (\%) }\end{array}$ & $\begin{array}{c}\text { Plastic index } \\
\text { PI }\end{array}$ \\
\hline S-14 & $20.55-21$ & ML & 21 & 19 & 76 & 5 & 22.4 & 27 & 4.1 \\
\hline S-15 & $22.05-22.5$ & SM-ML & 20 & 48 & 52 & 0 & 25.6 & 21.4 & 0.8 \\
\hline S-16 & $23.55-24$ & ML & 17 & 15 & 82 & 3 & 24.4 & 27.5 & 1.2 \\
\hline S-17 & $25.05-25.5$ & ML & 23 & 4 & 86 & 10 & 19.5 & 35.2 & 6.4 \\
\hline S-18 & $26.55-27$ & ML & 24 & 20 & 74 & 6 & 21.7 & 26.5 & 3.3 \\
\hline S-19 & $28.08-28.53$ & $\mathrm{CL}$ & 16 & 6 & 56 & 38 & 42.9 & 43.9 & 20 \\
\hline S-20 & $30-30.45$ & ML & 21 & 15 & 84 & 1 & 25.1 & 26.1 & 1.2 \\
\hline
\end{tabular}

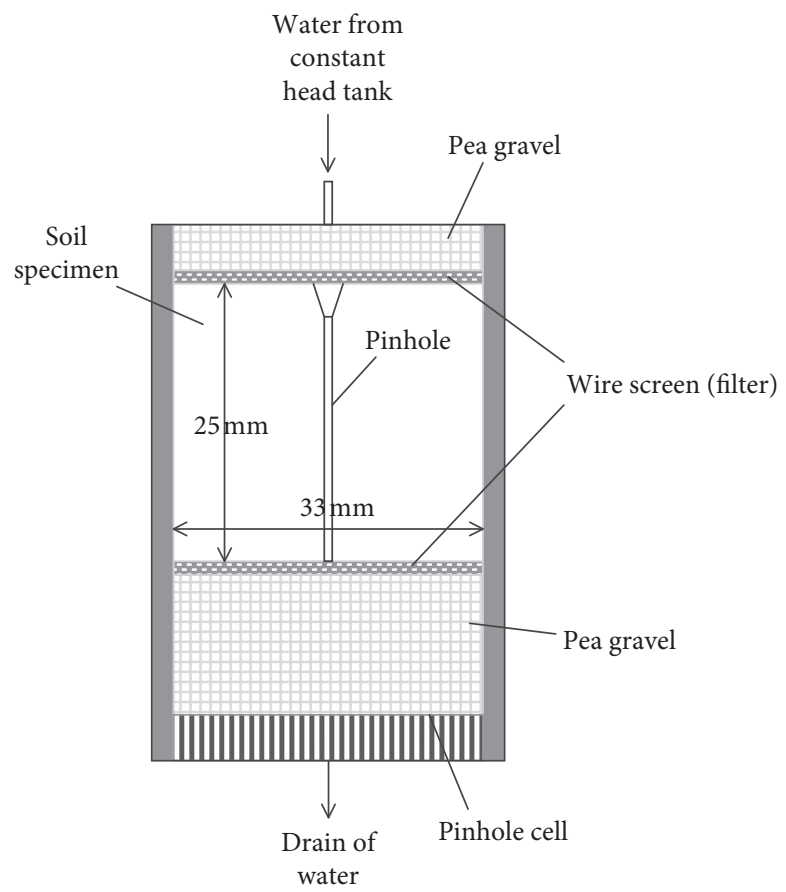

Figure 8: Pinhole test apparatus for assessing the dispersion and consequent erodibility of the local sandy silt.

TABLE 3: Summary of the pinhole test results.

\begin{tabular}{lccccc}
\hline Specimen no. & Final head $(\mathrm{mm})$ & Colour cloudiness & Pinhole size after test $(\mathrm{mm})$ & Specific surface area $\left(\mathrm{m}^{2} / \mathrm{g}\right)$ & Dispersion classification \\
\hline S-14 & 50 & Moderately dark & 3 & 3.20 & $\mathrm{D}$ \\
S-15 & 50 & Barely visible & 2 & 3.27 & $\mathrm{D}$ \\
S-16 & 50 & Moderately dark & 3 & 3.11 & $\mathrm{D}$ \\
S-17 & 50 & Dark & 4 & 2.95 & $\mathrm{D}$ \\
S-18 & 50 & Dark & 4 & 6.84 & $\mathrm{D}$ \\
S-19 & 180 & Clear & 1 & 3.07 & ND \\
S-20 & 50 & Moderately dark & 3 & D \\
\hline
\end{tabular}

Note: $\mathrm{D}=$ dispersive soil; $\mathrm{ND}=$ nondispersive soil.

erosion. It may be conclusively mentioned that the seepageprone weak zones and high hydraulic gradient initiated the water leak incident and that water from the two undermined water mains transferred the Kaohsiung silt into more flowable debris and its nonplastic nature aggravated the collapse even further. Despite an apparent inadequacy in dealing with similar incident in other sites, the local sandy silt was found to be prone to the piping at deep depths under large hydraulic gradients, and the two undermined water mains enhanced its flowable nature, thereby enlarging the scale of the water leak incident.

3.3. Lessons Learned. Quite often subway construction failures are not explained nor published, which makes the same mistakes to be made another time with great casualties and economic losses. Some bullet points that indicate what engineers should do or avoid are learned and summed up as follows: 
(i) Quality control for grouting: since in-ground obstructions such as wastewater and electricity mains can result in some difficulty in installing jet-grout columns exactly in the plumb, a trial grouting should be performed prior to the formal one to verify the design grouting parameters.

(ii) Seepage-prone weak zone: except for trial grouting, additional soilcrete columns, resulting from chemical grouting, should be considered during design phase and constructed next to jet-grout columns, which not only increases the length of path for the groundwater seepage but also prevents formation of the seepage-prone weak zone.

(iii) Local soil nature: the Kaohsiung silt contained in the sand has proved to possess high dispersion, or low strength, or both. There is a necessity to investigate the nature of local soils while progressing upcoming subway construction project if they are found to exhibit peculiar behaviour differentiated from common sense in soil mechanics.

\section{Concluding Remarks}

The main cause to lead to the water leak incident was investigated. The pinhole tests were conducted to highlight not only the nonplastic nature of the Kaohsiung silt but also its vulnerability to piping or internal erosion. Some main concluding remarks can be drawn as follows:

(1) The piping was responsible for initiating the water leak incident. Dumping sand bags and quick-set cement failed to ease the water leak. Mud water carried away fine particles in the ground and together flowed into the tunnels through the ripped liner joints leading to serious ground loss. Such ground loss caused two surface cave-ins. The surface cave-ins not only impeded traffic but also caused damages to adjacent properties.

(2) The hydraulic pressure at the point of water ingress was estimated to be about $300 \mathrm{kPa}$. The length of shortest path for groundwater seepage was from the bottom of the soilcrete body to the point of water ingress, that is, $2.4 \mathrm{~m}$, corresponding to the hydraulic gradient of 12.1 .

(3) The existing vehicle underpass led to some difficulties in installing the jet-grout columns exactly in the plumb, and some seepage-prone weak zones were thus developed. The seepage-prone weak zones allowed the water to flow through the jet-grout columns into the sump pit, and such high hydraulic gradient made the water inflow even greater. The combined effects were deemed as the main cause initiating the water leak incident.

(4) The results of the pinhole test identified not only the nonplastic nature of the Kaohsiung silt but also its vulnerability to piping or internal erosion under large hydraulic gradients. Water from the two undermined water mains and the nonplastic nature of the Kaohsiung silt aggravated the collapse even further. More detailed investigation is considered to be necessary to address the explored issue with different aspects of view.

\section{Data Availability}

The data used to support the findings of this study are included within the article.

\section{Conflicts of Interest}

The authors declare that they have no conflicts of interest.

\section{Acknowledgments}

This study would not have been possible without financial supports from the Special Fund for Basic Scientific Research of Central Colleges, Chang'an University, under Grant no. 300102269502 .

\section{References}

[1] Y.-S. Jo, S.-H. Cho, and Y.-S. Jang, "Field investigation and analysis of ground sinking development in a metropolitan city, Seoul, Korea," Environmental Earth Sciences, vol. 75, no. 20, p. 1353, 2016.

[2] Y. Hou, Q. Fang, D. Zhang, and L. N. Y. Wong, "Excavation failure due to pipeline damage during shallow tunnelling in soft ground," Tunnelling and Underground Space Technology, vol. 46, pp. 76-84, 2015.

[3] R. P. Chen, Z. C. Li, Y. M Chen, C. Y. Ou, Q. Hu, and M. Rao, "Failure investigation at a collapsed deep excavation in very sensitive organic soft clay," Journal of Performance of Constructed Facilities, vol. 29, no. 3, Article ID 04014078, 2015.

[4] S.-J. Feng and S.-F. Lu, "Failure of a retaining structure in a metro station excavation in Nanchang city, China," Journal of Performance of Constructed Facilities, vol. 30, no. 4, Article ID 04015097, 2016.

[5] Y. Tan and Y. Lu, "Forensic diagnosis of a leaking accident during excavation," Journal of Performance of Constructed Facilities, vol. 31, no. 5, Article ID 04017061, 2017.

[6] J. H. Shin, I. K. Lee, Y. H. Lee, and H. S. Shin, "Lessons from serial tunnel collapses during construction of the Seoul subway line 5," Tunnelling and Underground Space Technology, vol. 21, no. 3-4, pp. 296-297, 2006.

[7] Y. Tan and B. Wei, "Performance of an overexcavated metro station and facilities nearby," Journal of Performance of Constructed Facilities, vol. 26, no. 3, pp. 241-254, 2012.

[8] Y. Tan, B. Wei, X. Zhou, and Y. Diao, "Lessons learned from construction of shanghai metro stations: importance of quick excavation, prompt propping, timely casting and segmented construction," Journal of Performance of Constructed Facilities, vol. 29, no. 4, Article ID 04014096, 2015.

[9] W.-C. Cheng, J. C. Ni, J. S.-L. Shen, and H.-W. Huang, "Investigation into factors affecting jacking force: a case study," Proceedings of the Institution of Civil Engineers-Geotechnical Engineering, vol. 170, no. 4, pp. 322-334, 2017.

[10] W.-C. Cheng, J. C. Ni, A. Arulrajah, and H.-W. Huang, "A simple approach for characterising tunnel bore conditions based upon pipe-jacking data," Tunnelling and Underground Space Technology, vol. 71, pp. 494-504, 2018. 
[11] W.-C. Cheng, L. Wang, Z.-F. Xue, J. C. Ni, M. Rahman, and A. Arulrajah, "Lubrication performance of pipejacking in alluvial deposits," Tunnelling and Underground Space Technology, vol. 91, Article ID 102991, 2019.

[12] Z.-F. Wang, W.-C. Cheng, and Y.-Q. Wang, "Investigation into geohazards during urbanization process of Xi' an, China," Natural Hazards, vol. 92, no. 3, pp. 1937-1953, 2018.

[13] Z. Ye and H. B. Liu, "Mechanism and countermeasure of segmental lining damage induced by large water inflow from excavation face in shield tunneling," International Journal of Geomechanics, vol. 18, no. 12, Article ID 04018163, 2018.

[14] Z. C. Wang, Z. Hu, J. X. Lai, H. Wang, K. Wang, and W. B. Zan, "Settlement characteristics of jacked box tunnelling underneath a highway embankment," Journal of Performance of Constructed Facilities, vol. 33, no. 2, Article ID 04019005, 2019.

[15] R. Spruit, F. van Tol, W. Broere, E. Slob, and E. Niederleithinger, "Detection of anomalies in diaphragm walls with crosshole sonic logging," Canadian Geotechnical Journal, vol. 51, no. 4, pp. 369-380, 2014.

[16] J. Lai, J. Qiu, H. Fan et al., "Fiber Bragg grating sensors-based in situ monitoring and safety assessment of loess tunnel," Journal of Sensors, vol. 2016, Article ID 8658290, 10 pages, 2016.

[17] H. F. Xing, F. Xiong, and J. M. Wu, "Effects of pit excavation on an existing subway station and preventive measures," Journal of Performance of Constructed Facilities, vol. 30, no. 6, Article ID 04016063, 2016.

[18] J. Lai, S. He, J. Qiu et al., "Characteristics of seismic disasters and aseismic measures of tunnels in Wenchuan earthquake," Environmental Earth Sciences, vol. 76, no. 2, pp. 76-94, 2017.

[19] S. L. Shen, Z. F. Wang, and W. C. Cheng, "Estimation of lateral displacement induced by jet grouting in clayey soils," Géotechnique, vol. 67, no. 7, pp. 1-10, 2017.

[20] W.-C. Cheng, J. C. Ni, S. L. Shen, and Z.-F. Wang, "Modeling of permeation and fracturing grouting in sand: laboratory investigations," Journal of Testing and Evaluation, vol. 46, no. 5, pp. 2067-2082, 2018.

[21] Z.-F. Wang, J. S. Shen, and W.-C. Cheng, "Simple method to predict ground displacements caused by installing horizontal jet-grouting columns," Mathematical Problems in Engineering, vol. 2018, Article ID 1897394, 11 pages, 2018.

[22] W.-C. Cheng, J. C. Ni, H.-W. Huang, and J. S. Shen, "The use of tunnelling parameters and spoil characteristics to assess soil types: a case study from alluvial deposits at a pipejacking project site," Bulletin of Engineering Geology and the Environment, vol. 78, no. 4, pp. 2933-2942, 2019.

[23] W.-Y. Xia, Y.-J. Du, F.-S. Li et al., "In-situ solidification/ stabilization of heavy metals contaminated site soil using a dry jet mixing method and new hydroxyapatite based binder," Journal of Hazardous Materials, vol. 369, no. 5, pp. 353-361, 2019.

[24] W. L. Wang, "A study of reconstruction for ground settlement-the LUO09 shield tunnel for the Kaohsiung MRT system $\mathrm{CO}_{2}$ section," M.Sc. thesis, National Taipei University of Technology, Taipei, Taiwan, 2011.

[25] A. W. Skempton and J. M. Brogan, "Experiments on piping in sandy gravels," Geotechnique, vol. 44, no. 3, pp. 449-460, 1994.

[26] J. L. Sherard, E. F. Steele, R. S. Decker, and L. P. Dunnigan, "Pinhole test for identifying dispersive soils," Journal of the Geotechnical Engineering Division ASCE, vol. 102, no. 1, pp. 69-85, 1976.
[27] F. G. Bell and D. J. H. Walker, "A further examination of the nature of dispersive soils in Natal, South Africa," Quarterly Journal of Engineering Geology and Hydrogeology, vol. 33, no. 3, pp. 187-199, 2000.

[28] J. L. Sherard, L. P. Dunnigan, and R. S. Decker, "Some engineering problems with dispersive clays," in Proceedings of Symposium on Dispersive Clays, Related Piping, and Erosion in Geotechnical Projects, pp. 3-12, Chicago, IL, USA, June-July 1977.

[29] ASTM D4647-93, Standard Test Method for Identification and Classification of Dispersive Clay Soils by the Pinhole Test, American Society for Testing and Materials, West Conshohocken, PA, USA, 2006.

[30] J. Lu, T.-H. Wang, W.-C. Cheng, T. Yang, and Y. Luo, "Permeability anisotropy of loess under influence of dry density and freeze-thaw cycles," International Journal of Geomechanics, vol. 19, no. 9, Article ID 04019103, 2019. 


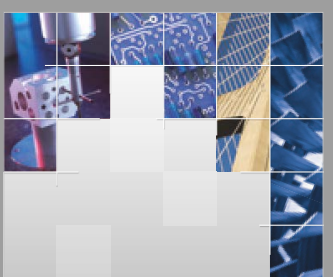

\section{Enfincering}
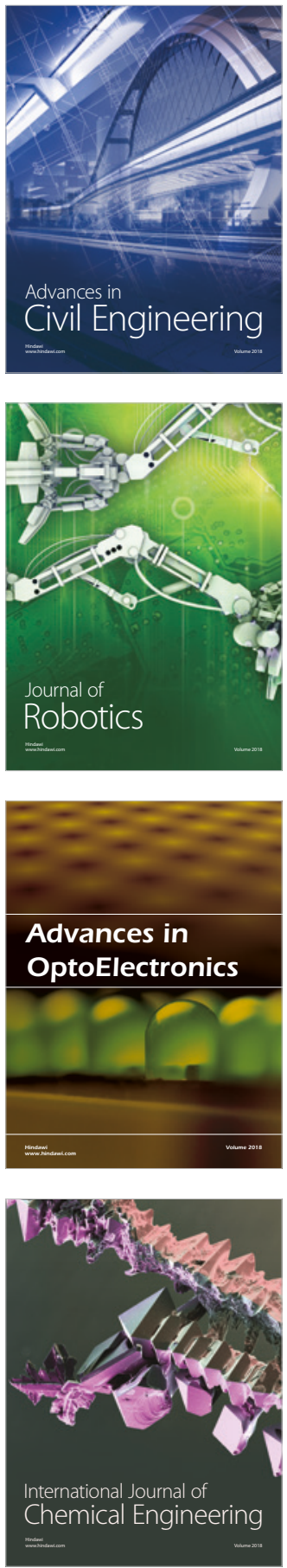

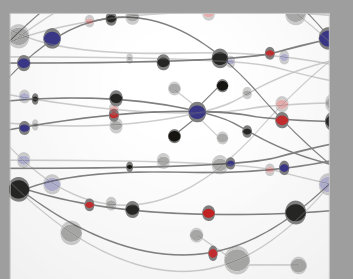

\section{Rotating \\ Machinery}

The Scientific World Journal

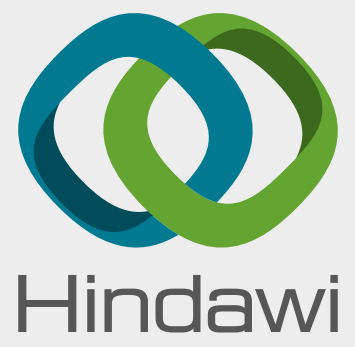

Submit your manuscripts at

www.hindawi.com
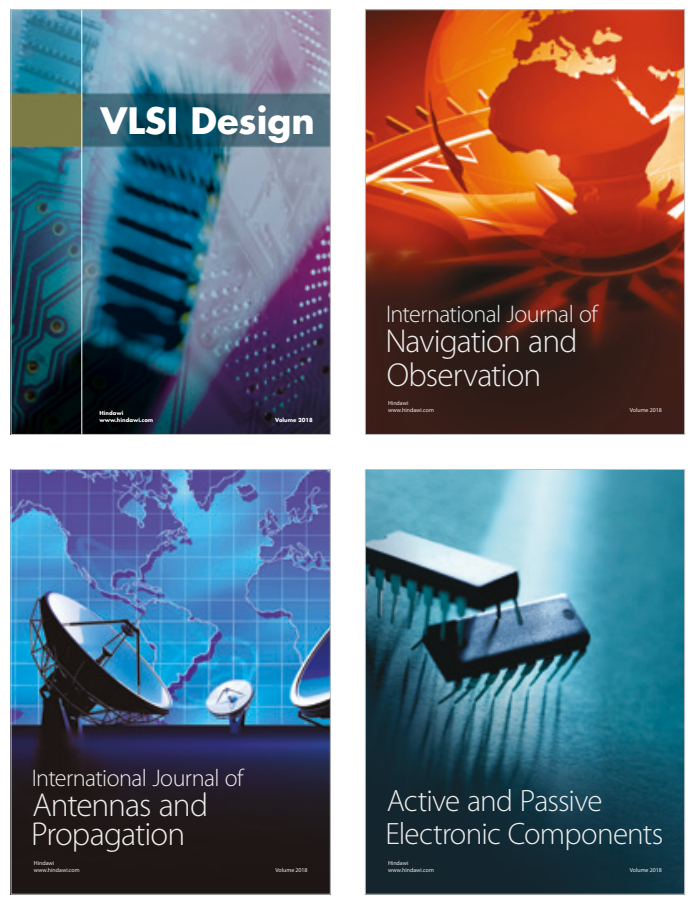
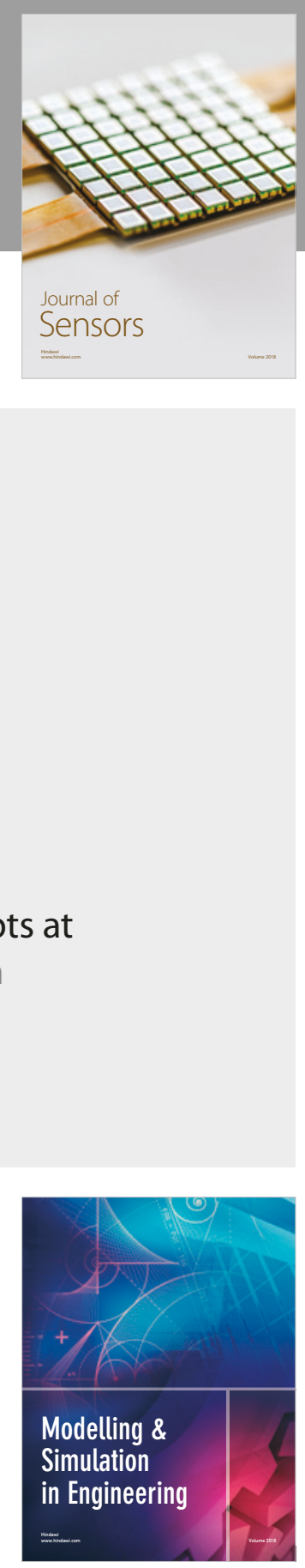

\section{Advances \\ Multimedia}
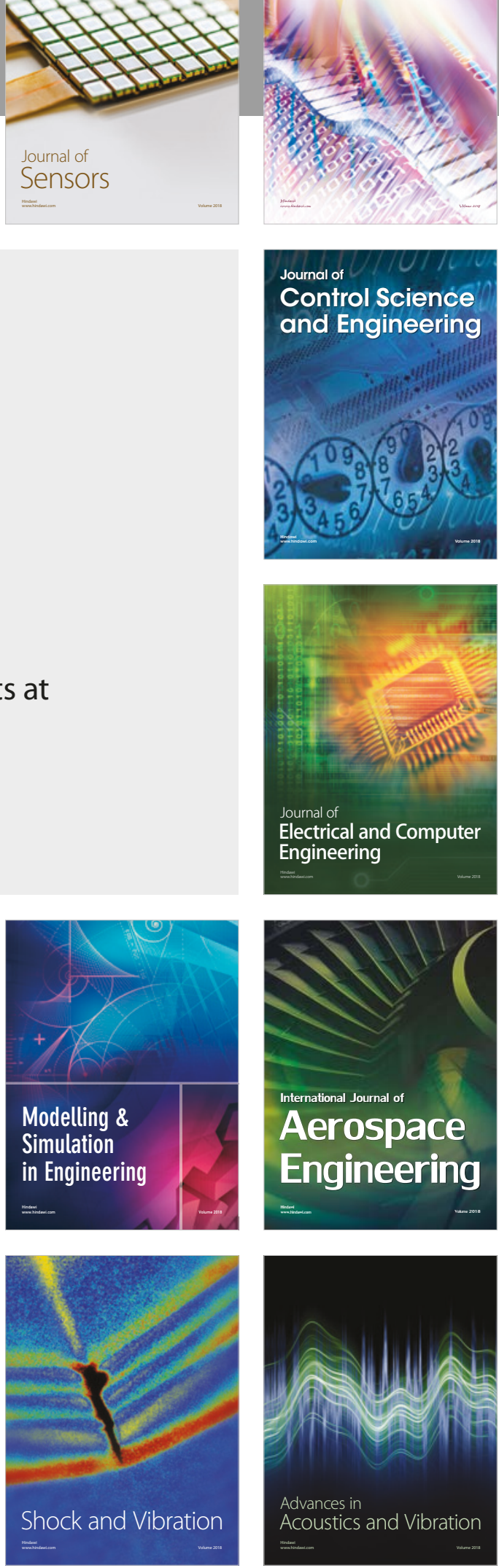